\title{
PUBLICIDADE E CORREÇÃO IDIOMÁTICA
}

A LINGUAGeM DA PUblicidade:

SUA Influencia na lingua portuguesa comum e no estilo

Norma Lücia Horta Neves*

Defendemos a existencia de uma "línguagem da publicidade, conceito que se superpöe a qualquer sistema linglistico.

A propaganda comercial brasileira, por exemplo, assenta suas bases na língua portuguesa, com a utilização de seus vārios ní veis:

a) Empregando palavras e expressōes da gíria contemporānea:

"Uma boa, curtir o som internacional na BOITE BAMGalô. Presença de tremendas cocotas codas as noites".

b) Usando versos, rimas, aliteraçöes, além de renovar "fra ses feitas".

"Ponha fé neste cafë"(CAFE MINAS-RIO)

"O que os olhos não sentem, o coraçäo näo vê"

(TVA - Televisão e Arte Cinematogräfica)

c) Utilizando, com fins expressivos, arcaísmos, neologismos e estrangeirismos, inclusive "lusitanismos", como no seguinte anúncio:

"Caramba, Sr. Fernandes! Por que cargas d'ägua näo anunciais em tempos de estio? ora vedes, Sr. Fernandes. Que sofismas argumen tais para calar os encômios que, a custa de queimar pestanas, os pa pa-natas aqui preparam para vossos producos?

Anunciai neste verão, Sr. Fernandes, e não vinde gastar saliva com as regrinhas de sazonage outras quinquilharias sebastianistas de que falavam os senhores pais dos pais dos pais dos vossos... Al que não, homem: Deixai de vez esta caturrice de trampa:" (AROLDO ARAUJO PROPAGANDA)

Mas a linguagem da comunicação publicitāria apresenta carac terísticas próprias, quando comparada com os outros níveis linglísti cos. Alēm de sua função bem definidas - a persuasão ao consumo - ela farjou uma originalidade e uma liberdade que, sem dúvida, constituem o seu traço mais marcante: liberdade no vocabulärio, pela criação

\footnotetext{
* Professora Adjunta da Faculdade de Letras da Universidade Federal de Minas Gerais. Doutora em Língua Portuguesa.
} 
incessante de neologismos; liberdade na sintaxe, com o uso abusivo de frases inorgānicas e de estruturas compactas; enfim, uma língua extremamente mōvel, sem apego à tradição idiomática, mais preocupa da com os procedimentos expressivos do que com o purismo idiomätco.

Não se deve, codavia, superestimar a sua influência sobre o português comum, seja no campo do vocabulärio, seja no da sintaxe ou do estilo.

os empréstimos vocabulares, por exemplo, por mais estranha que seja a sua formação em relação aos princípios filolögicos competentes, e por mais numerosos que sejam, nāo alteram a estrutu ra da língua.

o que pode acontecer,às vezes - e o fenômeno é comum em todas as línguas onde a publicidade se formaliza - $\vec{e}$ a incorpora çāo de nomes próprios, principalmente de marcas industriais, à classe dos nomes comuns. No português do Brasil, pelo menos no uso popular, pode-se dizer que as palavras BRAHMA (cerveja), GILETE ( $1 \underline{a}$ mina de barbear) e FENEME (veículo de transporte) estão sendo usadas designando espécies, além de serem marcas de producos.

Já no plano morfológico, merece especial atenção a influ éncia de prefixos e sufixos que, na maioria das vezes originados da nomenclatura técnica e científica, tornaram-se "publicitários"e, como tal, estenderam-se à formação de neologismos no. português comum e principalmente no uso literärio. Sirva de exemplo, entre outros, a terminação - $X$ ou -EX. Por outro lado, a liberdade da lín guagem publicitäria permite flexōes não aceitäveis na língua padräo. Exemplificando:

"Revendedora de Automóveis Belo Motores:FORDISSIMA:"

Quanto aos häbitos sintäticos, a linguagem da publicidade é responsāvel, talvez, pela difusão de certas estruturas não aceitas no uso culto, como, por exemplo, a adjetivação de nome prọ prio documentado no seguinte anúncio:

"Rio-sheraton: o hotel mais RIO DE JANEIRO do Rio de Janeiro"

Até que ponto se podem considerar "errados" ou "incorretos" os casos acima apontados?

Teoricamente, e- correto o que produz uma comunicação ef ciente. Na prática, porém, o convívio social impōe certas normas de comportamento, inclusive no desempenho linglístico, cuja corre- 
ção se baseia no uso culto. Mas essa linguagem dita "correta" não se exige rigorosamente em todas as circunstancias da vida social: o "certo" e o "errado" são conceicos relativos, pois dependem da situa ção, da opção do falante e da expectativa do interlocutor.

Cabe à escola, no ensino da língua materna, conscientizar os es tudantes da adequação de cada nível e registro e, em especial, do do mínio do uso culto quando seu papel na sociedade o exigir. Aos meios de comunicação de massa, bem como à literatura, caberia o reforço da divulgação dos modelos da língua-padrāo, pela importância de sua atuação no comportamento social, favorecendo a uniformização lingllisca.

Uma "boa linguagem" apresentaria, segundo MAtToso câMara JR. in Manual de Expressāo Oral e Escrita, três características fundamen tais :

"a) a adequação ao assunto pensado;

b) certo predicado estético que nos convida a encarar com boa vontade o exposto;

c) uma adaptação inteligente e sutil ao ideal linglístico cole tivo, o que importa no problema da correção gramatical"stric to sensu".

Excetuando-se, talvez, O item $C$, pode-se dizer que os anúncios comerciais brasileiros, em sua maioria, costumam apresentar essas ca racteristicas de "boa linguagem".

A maioria dos "erros gramaticais" da propaganda comercial (por exemplo na regência de alguns verbos, na mudança de tratamento, no uso de "ter" por "haver", etc) são fatos da lingua portuguesa popular que começam a se introduzir no uso corrente e até mesmo na língua li teräria contemporânea, conforme nos demonstra lUIz CARLos LESSA, no interessante estudo o Modernismo Brasileiroe a Língua Portuguesa.

Entretanto, hä certos "erros" - no sentido de desvio à norma cul ca - que pertencem à língua da publicidade, donde se irradiam para o uso corrence, à força de serem repetidos. Vejamos, alguns exemplos, no campo da ortografia:

ECONOMISA (financeira); BAMGALO (boate); MAIZENA (amido de mi1ho); INGLEzA (cera); FleXA (artigos plásticos); suissa (balas)etc.E lögico que essas grafias não obedecem ao modelo ortogräfico vigente. Em alguns casos, sāo marcas registradas antes da reforma da ortografia, em 1943. Seria necessäria a sua correçāo agora, por interesses puristas ou pedagögicos? Cremos que näo. Entretanto, nāo se justificam as grafias incorretas em marcas de produtos e em denominações có 
comerciais surgidas depois daquela data.

Ainda na ärea da grafia, temos um caso interessante: as esti lizações grāficas, como as que se seguem:

FELI\$ NATAL; LIQUIDA\$\$\$̃̃o; LEEQUIDAÇÃO.

Elas valem pelo pitoresco, chamam a atenção e não afetam o uso culto. Säo, de qualquer forma, realmente "publicitärias".

Outras construções normais da publicidade podem-se conside rar incorretas, do ponto de vista normativo.E o caso de expressões como METRÓPOLE HOTEL (os puristas preferem a colocação hOTEL METROPOLE); XICO'S BAR (sintaxe anglicizanta) e VENDA-MONSTRO ("mot-bloc:").

Evidentemente, podemos encontrar na língua da publicidade cer cos "erros" que refletem a ignorāncia ou a pouca culcura do comerciante ou do redator profissional. Mas são casos esporádicos, constituem um desvio à norma por desconhecimento de língua culta, e näo por intenção estilística:

MOVEIS UZADOS; SANDALHAS; VENDAS A PRAZO etc.

o descaso dos comunicadores de massa no uso do português gene ralizou-se a tal ponto que o Governo anunciou, há pouco tempo, uma "campanha em defesa da língua". Mandou publicar, pela Academia Brasi leira de letras, uma cartilha com os erros que mais se cometem na prensa falada, escrita e televisada. E claro que a publicidade, pelo menos na comunicação de massa, não terá muita responsabilidade no problema. Seus comerciais são policiados por especialistas e conhecedores da lingua padrão; eles raramente deixam escapar incorreçōes gramaticais que prejudiquem a boa imagem da firma ou do produto anun ciado.

E na propaganda local, individualizadora, de anunciantes in cultos, que mais se justifica a preocupação do Governo e dos professores de Português.

Ao contrārio do que se pensa, é no âmbito do estilo - e não no do sistema - que a língua da publicidade parece exercer a sua maior influência. Ela se faz sentir principalmente em duas direçós:

a) contribuindo para o enriquecimento do vocabulärio comum, a travēs da divulgação de palavras e expressōes peculiares às línguas especiais da ciência e da tecnologia. Nomes científicos de doençs, novidades tecnológicas, eruditismos latinos e gregos tornam-se familiares ao grande público.

Veja-se, por exemplo, um trecho do longo anúncio das MASTIGUI NHAS : 
"MAStiguinhas é o novo complexo vitaminico em forma de pastilhas mastiáveis. Cada pastilha tem as nove vitaminas, cuidado samente dosadas e balanceadas, que seu filho precisa para crescer forte e sadio".(Arrolam-se, a seguir, os componentes do produto,den tre eles a "Nicotinamida" e "Pantotenato de Cálcio"). Saliente-se que o texto não pertence à categoria das "bulas" ou das informações cientificas destinadas $P a$ classe médica. E um comercial divulgado para o grande público.

vale a pena ser lembrado, a propósito, um conhecido comer cial dos producos DANONE, na televisão, em que o filho corrige os pais, quando os chamam prosaicamente "queijinhos".

b) incentivando o gosto pelo exagero, pela ênfase, por um estilo retōrico que não condiz coma melhor forma de expressão mo derna. Aí estā, a nosso ver, a influência realmente negativa da lín guagem publicitāria. Mas ela não estā sozinha nessa ação deturpadora do estilo. Também exercem a mesma influência outras formas de co municação de massa - por exemplo o jornalismo sensacionalista e a eloquência política. Todos eles têm um ponto em comum: a informação persuasiva.

Em resumo, não acreditamos que a língua portuguesa da publicidade seja um dos grandes responsāveis pela decadência da lín gua culta. Se ela de algum modo contribui para isso, serā menos pelos "erros" que generaliza do que pela acmosfera de negligência e dé liberdade que sugere.

Pois ela pode levar o usuärio da lingua a um relaxamento verbal, a um controle menos rígido da expressãoe, o que è mais sẹ rio, a uma preocupação maior como efeito do que com a precisão das idèias.

Finalmente, essa decadēncia da "língua culta", täo lamentada pelos defensores da "boa linguagem", não constitui um fato iso lado da nossa cultura nem se justifica, exclusivamente, pela ação "corrosiva" dos meios de comunicąão de massa - nela incluída a publicidade ou propaganda comercial. Como todo fenómeno lingllístico, a influência da linguagem publicitaria sobre a língua portuguesa só será bem compreendida quando analisada dentro de um contexto cultural mais amplo. 


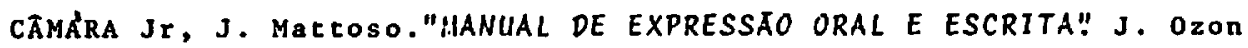
Editor, Rio de Janeiro, 1961

Castilho, ataliba de (et alii) PANORAMA DA SOClolinguIstica. Revis ta de Cultura Vozes ne 7, Petrópolis,

CUNHA, Celso. LINGUA PORTUGUESA E REALIDADE BRASILEIRA. Tempo Brasileiro, Rio de Janeiro, 1970

Galliot, Marcel. "ESSA sur la langue de la reclame contemporatne" Privat, Toulouse, 1955

LEDUC, Robert. PROPAGANDA: UMA FORÇA A SERUIÇO DA EMPRESA. At las, são Paulo, 1972

LESSA, Luiz Carlos." O MODERNISMO BRASILEIRO E A LINGUA PORTUGUESA", Getülio Vargas, São Paulo

MARCUS-STEIFF, Joachim (et alii). "OS MITOS DA PUBLICIDADE" Vozes, Petröpolis, 1974

MELO, Glastone Chaves de."A decadência da língua culta e suas causas" in"CONVERGENCIA", Revista Cultural do Centro de Estudos do Real Gabinete Português de Leitura, ano $I, n 81$, Río de Janeiro, 1976

NEVES, Norma Lücia h."NOMES PROPRIOS COMERCIAIS E INDUSTRIAIS NO PORTUGUES. Imprensa oficial, Belo Horizonte, 1971 